\title{
Postpartum Dysgalactia Syndrome in Swine-An Update
}

\author{
B. Balamurugan ${ }^{1 *}$ and R. Selvarani ${ }^{2}$ \\ ${ }^{1}$ Department of Veterinary Gynaecology \& Obstetrics, BHU-Faculty of Veterinary \& Animal \\ Sciences, Rajiv Gandhi South Campus, Barkachha,Mirzapur, (U.P), India \\ ${ }^{2}$ College of Medicine, Department of Biochemistry and Molecular Biology, University of \\ Oklahoma, Health Sciences Centre, Oklahoma City, Oklahoma, USA \\ *Corresponding author
}

\section{A B S T R A C T}

\begin{tabular}{|l|}
\hline Ke y w or d s \\
$\begin{array}{l}\text { Sow, Postpartum } \\
\text { dysgalactia } \\
\text { syndrome and piglet }\end{array}$ \\
\hline Article Info \\
\hline $\begin{array}{l}\text { Accepted: } \\
\text { 08 June } 2020 \\
\text { Available Online: } \\
\text { 10 July 2020 }\end{array}$ \\
\hline
\end{tabular}

Postpartum dysgalactia syndrome is a disease of sows with multiple etiologies. Generally this disease occurs within 12 to 24 hrs post farrowing. This syndrome is caused by many of factors, the most important of which, are improper management, sanitation and infection. Variety of infectious organisms like E. coli, Streptococci sp, Staphylococci $\mathrm{sp}$, Klebsiella $\mathrm{sp}$, Mycoplasma sp are responsible for this condition. Lacks of exercise, endocrine factor and toxic factors are other contributing factors. The incidence is vary from 27 to $32.7 \%$. Around $20-25 \%$ loss of piglets at pre-weaning stage. The affected sow showing the clinical signs of swollen, firm, discolored mammary glands, painful to touch and foul smelling vaginal discharge. The principle of the treatment includes uses of broad antibiotics to control the bacterial infections, anti-inflammatory drugs to control the inflammation and use the drugs to stimulate or to secrete the milk.

\section{Introduction}

Rearing of swine is a key component of Animal husbandry, particularly in North eastern parts of India. Being a prolific breeder its gaining popularity as a meat animal in this region of the country dominated by pork consuming populations.

Several managemental factors influence the incidence of diseases in swine farms, out of which postpartum dysgalactia syndrome (PPDS) is a wide spread disease of pig with multiple etiology, that inflicts considerable economic damage causing severe piglets mortality. It is a complex syndrome causes $40 \%$ morbidity in swine farming. The disease occurs within 12 to 24 hours after farrowing and is characterized by anorexia, restlessness, inattentive to the piglets, fever, agalactia, swelling of mammary glands (Radostits et al., 2006).

In the old literature Postpartum dysgalactia syndrome (PPDS) called as Mastitis Metritis Agalactia (MMA) syndrome. 
On the other hand, lactation problems after farrowing do usually not show all three symptoms (Mastitis Metritis Agalactia). It is an economically important multi-factorial complex syndrome (Gerjets et al., 2009).

This disease has in recent years become one of the most perplexing problems facing the piggery industry. National pork producer association is also listed as a number one swine health problem. This disease ranks first or second in losses incurred by the swine producer. Losses are due to death of the piglet and unthriftiness of survivors.

\section{Incidence}

PPDS has occurred worldwide and seems to have no predilection as far as age of the animal is concerned (first, second litter, etc.). Most of the cases are reported in confinement facilities, although it can occur with pasture farrowing facilities. The severity and morbidity of PPDS varies from farm to farm.

This disease has been reported in both well and poorly managed farms. The mortality in affected sows is low, 1-2\%, but piglet losses was reported that $20-25 \%$ at pre-weaning stage (Kumaresan et al., 2006) however it was varied from $20-80 \%$ due to starvation, hypoglycemia and overlaying by the sows.

\section{Synonym of the syndrome}

Some of the names in the literature used to describe PPDS such as parturient fever, sow agalactia, toxemic agalactia, mastitis-metritis syndrome (MMA), milk fever, and lactation failure.

\section{Etiology}

The precise etiology of PPDS has not been elucidated, but many infectious and noninfectious causes have been incriminated.

\section{Management procedures}

Some of the management procedures which have been stated as being possible causes are: feeding alfalfa meal, Vitamin E or Selenium deficiency, Vitamin B12 deficiency, overfeeding of concentrates prior to farrowing, ending of concentrates prior to farrowing, lack of bulk in the ration, $\mathrm{Ca}: \mathrm{PO}_{4}$ imbalance in the ration and excess protein in the feed.

\section{Infectious agents}

Infectious agents which have been incriminated include: E. coli, Klebsiella sp., Proteus, Pseudomonas, Enterobacter, Citrobacter, Staphylococcus, Beta hemolytic Streptococci and Mycoplasma (Kemper et al., 2009).

\section{Toxic factors}

Toxic factors incriminated include ergotoxinfrom feeding moldy rye, aflatoxin and estrogens (Fusarium)-from feeding moldy corn.

\section{Bacterial endotoxins}

Bacterial endotoxins have been incriminated as a possible cause due to' the constipation often seen with PPDS.

\section{Vitamin deficiency}

Sow showed agalactia symptom when fed with inadequate amount of vitamin $\mathrm{E}$ in the diet (Mahan 1991).

\section{Endocrine dysfunction}

Endocrine dysfunction has also been reported as a possible etiological agent because of reported changes in ovarian size, structural changes in the adrenal gland, and response to 
oxytocin, prednisolone and dexamethasone. The reasoning behind this being that mammogenesis and lactation are a complicated interaction of the ovaries, pituitary gland and thyroid gland.

\section{Litter size}

The incidence of the disease also be higher in sows with larger litters than small litter size.

\section{Stress}

Stress has also been incriminated as a possible cause. Stresses associated with farrowing might be emotional (onset of parturition), thermal (temperatures different from normal), confinement (being enclosed in a tight stall), or environmental changes (i.e., odors in a confinement farrowing house).

\section{Hereditary}

Hereditary also one of the contributing factor for this syndrome (Roberts, 1971).

\section{Clinical signs}

The sow usually appears to be healthy, eats, drinks, and nurses the pigs for the first 12-24 hours (occasionally 36-48 hrs.) post farrowing. Affected sows after this rapidly lose in milk production. Appetite is usually completely lacking and signs of tiredness and sluggishness are manifest. Sows lie down on their abdomen to protect their udder. The sow seems insensitive (loss of maternal instinct) to squealing, hungry, rooting pigs which are trying to nurse. This is probably an attempt to cool the udder and prevent the pigs from nursing.

Generally, the sows will run a temperature ranging from normal $102.5^{\circ} \mathrm{F}$ ) to several degrees above normal $\left(105^{\circ}-107^{\circ} \mathrm{F}\right)$. The mammary glands are hot, swollen, firm, discolored and painful to touch. There are no strong changes in the visual appearance of the milk. The $\mathrm{pH}$ of the milk in PPDS affected sows is usually more alkaline (7.0-7.2) than the normal (6.4-6.5).

There may be a discharge from the vulva, but this is variable. A normal sow's lochia is sparse, muco-purulent, and often not observed (Fig. 3). In PPDS the lochial discharges are watery to thick muco-purulent and in general in greater quantity and less homogenous than normal lochial discharges. These discharges normally cease 3-6 days after farrowing. Often a change in demeanor of the sow occurs ranging from semi-comatose to aggressive and irritable. The sow may also have a hoarse characteristic voice. The sow may be constipated with little or no feces being voided in the last 24 hours prior to onset of symptoms. The agalactia (which is the only constant sign) or hypogalactia is a result of the sow refusing to milk letdown or milk production so scanty that the pigs starve. Pustules and erythematous lesions are observed around the skin of the udder in some pigs (Fig:1).

\section{Clinical signs in piglets}

Often piglets show the signs of hypoglycemia retarded average daily weight gain, starvation, ear-piercing, hypothermia, varying degrees of enteritis and diarrhea were frequently observed.

\section{Differential diagnosis}

All sows exhibiting hypogalactia or complete agalactia do not show the typical syndrome. In many of these cases, the causes of the lack of milk secretion can be determined and corrective or preventive measures taken.

It is essential therefore, to make an accurate differential diagnosis. 
Table.1 Treatment done by different authors

\begin{tabular}{|c|c|c|}
\hline S.No & Treatments & Authors \\
\hline 1 & $\begin{array}{l}\text { Inj. Enrofloxacin @ } 5 \mathrm{mg} / \mathrm{kg} \text { IM daily for } 3 \text { days, Inj. Meloxicam @ } \\
0.4 \mathrm{mg} / \mathrm{kg} \text { IM daily for } 3 \text { days, Inj. Oxytocin @ } 20 \mathrm{IU} \text { IM twice daily } \\
\text { for } 3 \text { days, oral calcium } 50 \mathrm{ml} \text { twice daily for } 7 \text { days and lukewarm } \\
\text { water dissolved with common salt was applied over the udder. Sow } \\
\text { showed peaceful recovery } 2 \text { days post treatment. }\end{array}$ & (Nath et al., 2016) \\
\hline 2 & $\begin{array}{l}\text { Inj. Ceftiofur Sodium @ } 2.0 \mathrm{mg} / \mathrm{kg} \text { IM daily for } 3 \text { days, Inj. Flunixin } \\
\text { meglumine @ } 0.25 \mathrm{mg} / \mathrm{kg} \text { IM daily for } 3 \text { days, Inj. Oxytocin @ } 20 \mathrm{IU} \\
\text { IM twice daily for } 3 \text { days, inj multivitamin with seratiopeptidase blous } \\
\text { was continued for } 3 \text { day and sow had uneventful recovery } 2 \text { days post } \\
\text { treatment. }\end{array}$ & (Bhuyan et al., 2015) \\
\hline 3 & $\begin{array}{l}\text { Inj. Amoxicillin@ } 15 \mathrm{mg} / \mathrm{kg} \text { IM for } 2 \text { days and Inj. Ketoprofen } \\
3 \mathrm{mg} / \mathrm{kg} \text { for } 2 \text { days. Sow showed uneventful recovery } 2 \text { days after } \\
\text { treatment.. }\end{array}$ & (Sabate et al., 2012) \\
\hline 4 & $\begin{array}{l}\text { Inj. Enrofloxacin @ } 5 \mathrm{mg} / \mathrm{kg} \text { IM daily for } 3 \text { days, Inj, Oxytocin @ } 20 \\
\text { IU IM twice daily for } 3 \text { days, oral mineral mixture @ } 25 \mathrm{~g} / \text { day daily up } \\
\text { to the weaning and sow recovered uneventfully within seven days. }\end{array}$ & (Kumaresan et al., 2009) \\
\hline 5 & $\begin{array}{l}\text { Inj. Enrofloxacin @ } 2.5 \mathrm{mg} / \mathrm{kg} \text { IM daily for } 3 \text { days, Inj. Flunixin } \\
\text { meglumine @ } 2 \mathrm{mg} / \mathrm{kg} \text { IM daily for } 3 \text { days, Inj. Carbetocin @ } 0.0007 \\
\mathrm{mg} / \mathrm{kg} \text { IM twice daily for } 3 \text { days. }\end{array}$ & (Hirsch et al., 2003) \\
\hline 6 & $\begin{array}{l}\text { Liquid: Exapar@ @ } 30 \mathrm{ml} \text { twice daily for } 3 \text { days along with Bouls: } \\
\text { Payapro } 2 \text { boli/day for } 10 \text { days and topical ointment AV/AMP/14 on } \\
\text { affected teats. }\end{array}$ & (Agrawal, 1998) \\
\hline
\end{tabular}

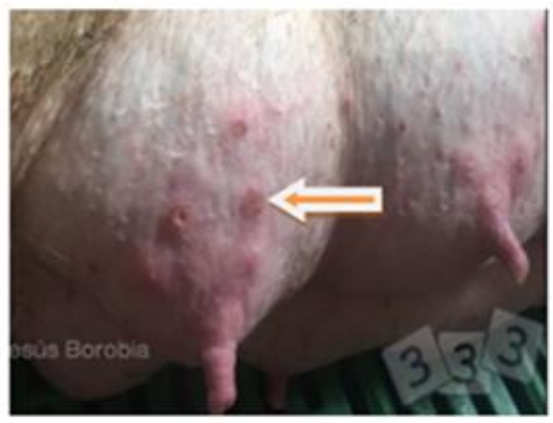

Fig.1 Pustules around the skin of the udder

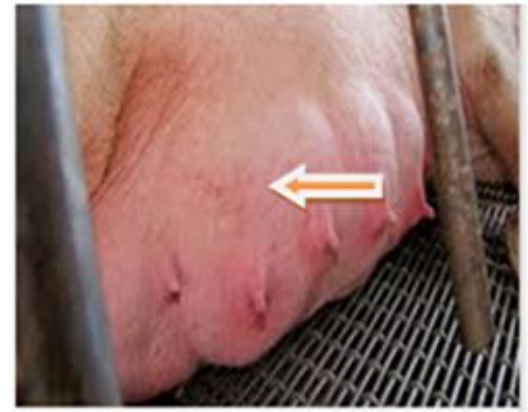

Fig.2 Oedema of the mammary gland

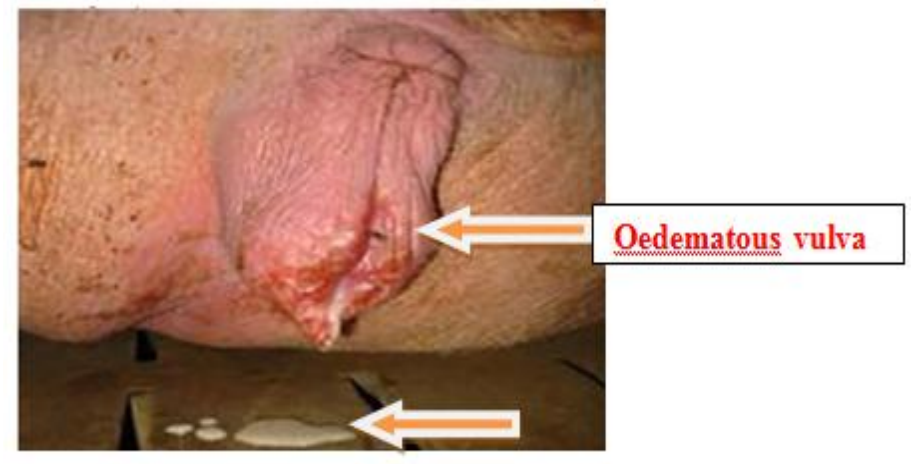

Fig.3 Muco-purulent vaginal discharge 


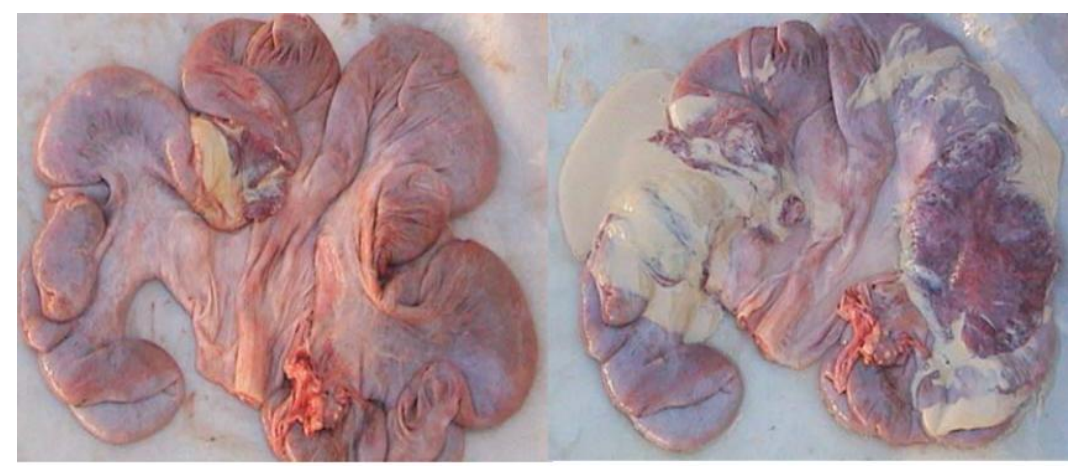

Fig.4 Uterus of the pig affected with postpartum dysgalactia syndrome

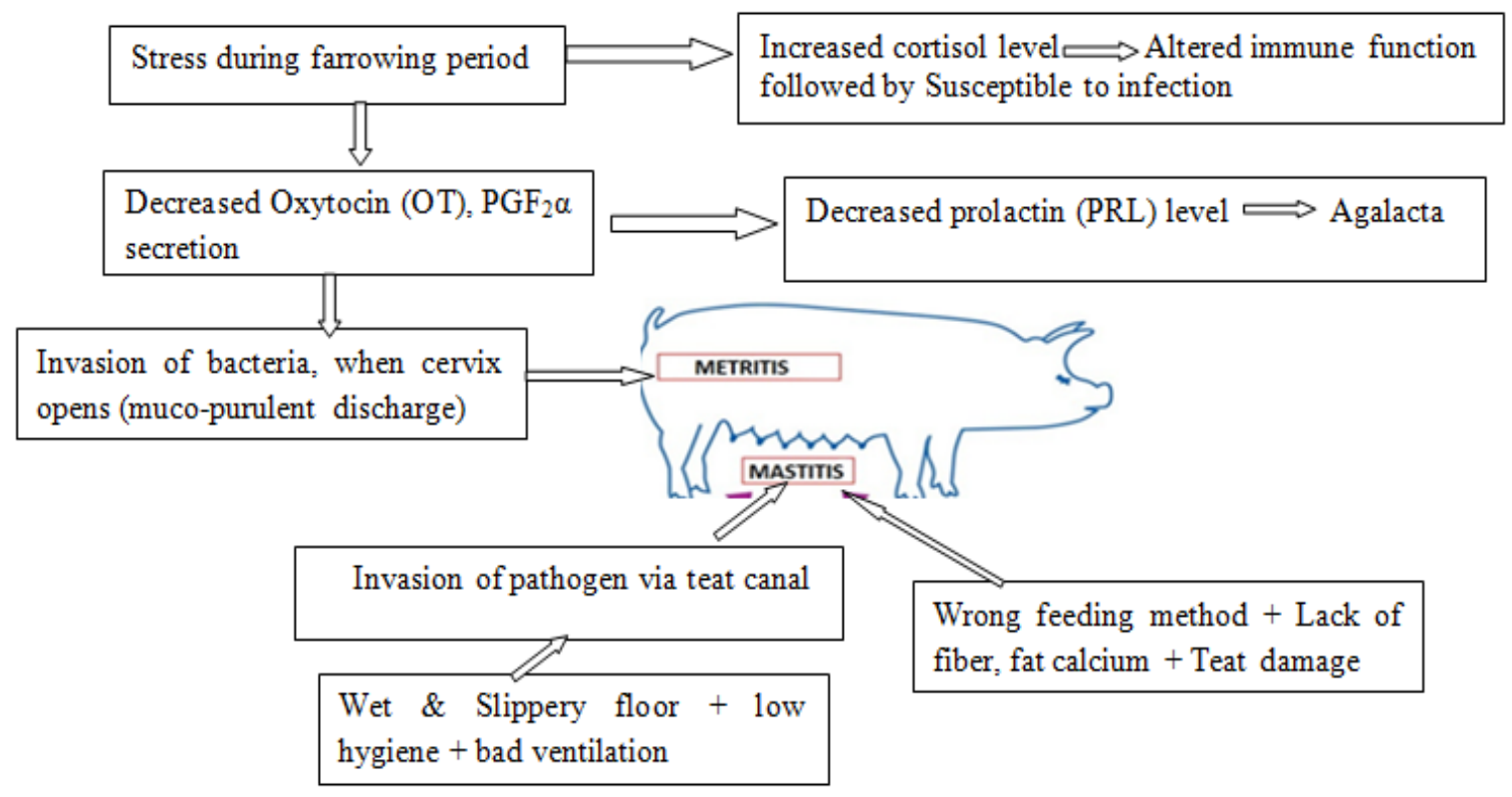

Fig.5 Etiology and possible mechanism of PPDS

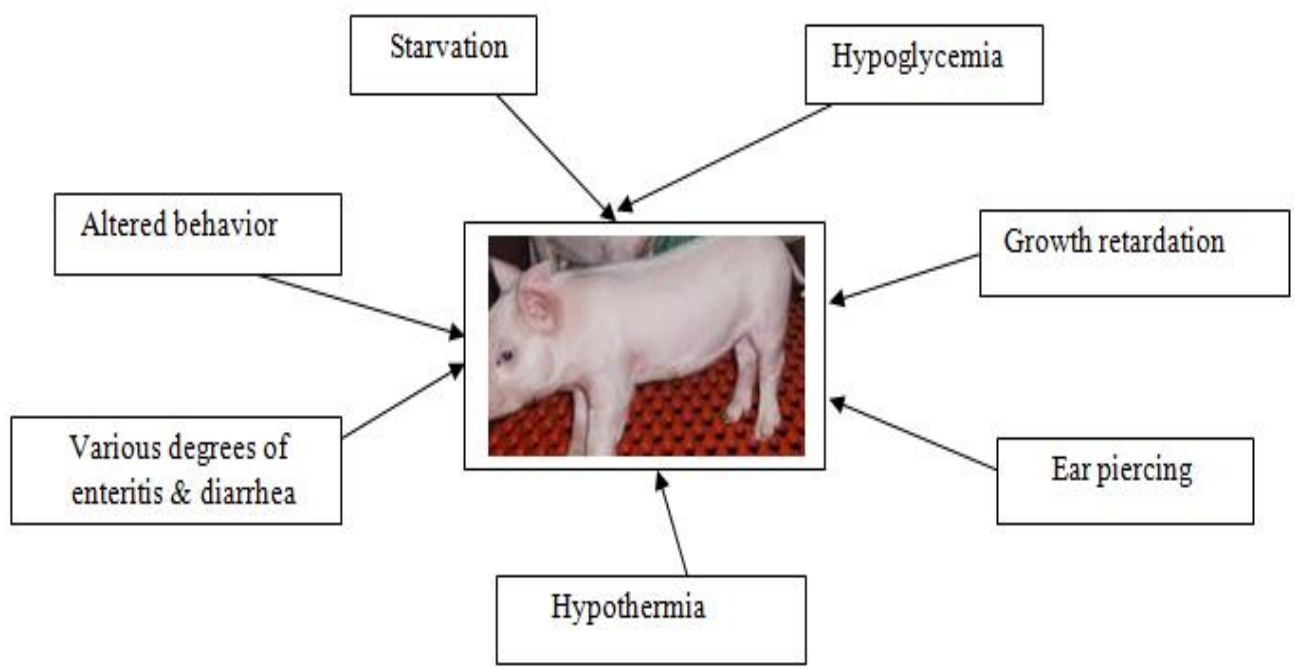

Fig.6 Clinical signs in piglets 


\section{Causes of agalactia}

Hypocalcemia or eclampsia (rare, can be treated with $\mathrm{Ca}, \mathrm{Mg}$ products). Chronic ergot hypoplasia (usually seen in gilts, insufficient prolactin release)

\section{Udder and teat conditions}

Teat necrosis, actinomycosis of udder, Traumatic agalactia and Inverted nipples

Failure of milk let-down mechanism (responds to single injection of Oxytocin) Acute bacterial mastitis

Any septicemia (Erysipelas, influenza, hog cholera, transmissible gastroenteritis, etc.)

Retained placenta with accompanying infection (usually exhibits foul-smelling vaginal discharge)

Piglet diarrhea

\section{Treatment}

The principle of the treatment includes uses of broad spectrum antibiotics to control the different bacterial infections. Most commonly used antibiotics include ampicillin, teracyclines, trimethoprim-sulphonamide and enrofolxacin. Anti-inflammatory drugs to reduce the postpartum oedema, pain, inflammation as well as anti-endotoxic action, that include Meloxicam, ketoprofen flunixin meglumine or corticosterioids (Prednisolone and dexamethasone) and use the drugs to stimulate or to secrete the milk that is oxytocin (pitocin, carbetocin and Syntocinon). Piglets should receive sow colostrum through stomach tube or by sucking of other sow, or be left with their mother and fed artificially until the sow get recovers.

\section{Prognosis}

Prognosis for the life of the affected sow is good. Prognosis for the complete return or establishment of normal lactation is guarded. The affected sow usually recovers in two to five days with or without lactation function.

\section{Prevention and control}

Good hygienic practice is a most effective way of prevention

The farrowing pen must be kept clean with antiseptic solution and dry throughout the period inorder to reduce bacterial challenges.

Sows should get more exercise before farrowing as well as early lactation may be less prone to developing PPDS.

Adequate treatment should given when the body temperature of the sow is $39.4^{\circ} \mathrm{C}$, 12-18 hours after farrowing.

Antibiotic therapy given when the sow had symptoms of fever, mastitis and metritis.

Advisable antimicrobial agents are amoxicillin, tetracyclines, enrofloxacin and trimethoprim sulphonamide.

Anti-inflammatory drugs such as ketoprofen, Meloxicam, flunixin meglumine or corticosteroids may helps in improving the recovery.

The use of oxytocin in early cases may reduce the need for veterinary involvement.

Feed medication with trimethoprim: sulphonamide at $15 \mathrm{mg} / \mathrm{kg}$ body weight or tetracyclines from day 112 of gestation to day 1 post-partum reduces the incidence of the PPDS.

\section{References}

Agrawal, A. 1998. Herbal therapy of metritismastitis-agalactia syndrome in sows. Indian Veterinary Journal. 75: 144 146.

Bhuyan, M., Barman, U., Acharya, C and Baishya, B,C. 2015. Clinical 
management of mastitis-metritisagalactia syndrome (MMA) in sow. International Journal of Recent Scientific Research, 6: 5143-5144.

Gerjets, I and Kemper N. 2009. Coliform Mastitis in Sows: A Review. Journal of Swine Health Production, 17, (2): 97105.

Hirsch, A.C., Philipp, H and Kleemann, R. 2003. Investigation on the efficacy of meloxicam in sows with mastitismetritis-agalactia syndrome. Journal of Veterinary Pharmacology and Therapeutics, 26: 355-60.

Kemper, N., Reiners, K and Gerjets, I. 2009. Analysis of the Pathogens Spectrum and Associated Risk Factors in Sow Postpartum Dysgalactia Syndrome (PPDS). Safe Pork, 275-277.

Kumaresan, A., Pathak, K,A., Bujarbaruah, K.M and Das, A. 2006. Swine Production in Mizoram. Research Bulletin No 48. Published by ICAR Research Complex for NEH Region, Barapan, Meghalaya.

Kumaresan, A., Bujar Baruah, K.M., Pathak, K.A, Chhetri, B and Ahmed, S.K. 2009. Clinical Management of Metritis-
Mastitis-Agalactia Syndrome (MMA) in pigs. Intas Polivet, 10(1): 117119.

Mahan, D.1991. Assessment of the influence of dietary vitamin $\mathrm{E}$ on sows and offspring in three parities: reproductive performance, tissue tocopherol, and effects on progeny. Journal of Animal Science, 69: 2904-2917.

Nath, M, K. and Kalita D. 2016. Mastitismetritis-agalactia syndrome (MMA) in sow: a case report. International journal of agriculture science and veterinary medicine, 4 (3):83-85.

Radostits, O.M., Gay, C.C., Hinchcliff, K.W. and Constable. P.D.2006. Veterinary Medicine, $10^{\text {th }}$ Edn, Elsevier publication,UK,754-759.

Roberts SJ. 1971. Veterinary Obstetrics and Genital Diseases. $2^{\text {nd }}$ edn. CBS Publ. pp 660.

Sabate, D., Salichs, M., Bosch, J., Ramio, P., Homedes, J. 2012. Efficacy of ketoprofen in the reduction of preweaning piglet mortality associated with subclinical forms of post-partum dysgalactia syndrome in sows. The pig journal, 67:19-23.

\section{How to cite this article:}

Balamurugan, B. and Selvarani, R. 2020. Postpartum Dysgalactia Syndrome in Swine-An Update. Int.J.Curr.Microbiol.App.Sci. 9(07): 787-793. doi: https://doi.org/10.20546/ijcmas.2020.907.090 